\title{
DISSEMINATED DEMYELINIZATION OF THE GENTRAL NERVOUS SYSTEM IN MONKEYS AND ALLIED DISORDERS IN MAN*
}

\author{
By \\ CHARLES DAVISON, New York
}

Among a group of monkeys which were brought to Germany in the last two years a number suddenly developed a progressive paralysis of the lower extremities and succumbed to the disease within a short period. The ætiology for this neurological disorder has not yet been definitely established. The histopathology of the nervous system, however, was carefully studied by Schob ${ }^{1}$ and Scherer. ${ }^{2}$ The white matter of the cerebral hemispheres in most of the monkeys showed a fairly uniform picture which consisted of numerous small demyelinated plaques. Some of these fused, forming larger plaques, resembling those seen in diffuse sclerosis. The pathological process in the spinal cords, however, was not the same in all the animals. In some, the process was analogous to that observed in tabes dorsalis (Schob); in others there was a demyelinization of most of the fibre tracts, especially of the posterior and lateral columns, similar to subacute combined degeneration (funicular spinal disease) (Scherer) ${ }^{2}$; in still others there was merely a descending degeneration of the crossed pyramidal tracts. In addition to involvement of the white matter of the hemispheres and spinal cord, the optic nerves and tracts in most of these monkeys showed pathological changes.

The similarity in the pathological process of these animals to that seen in diffuse sclerosis, subacute combined degeneration (funicular spinal disease) and a process $I$ observed in the nervous system in a case of generalized xanthomatosis, justifies the neural histopathological description of the following baboon (Papio cynocephalus) which Professor Spielmeyer was kind enough to permit me to study.

\section{REPORT OF A GASE}

Not unlike the orang-outangs described by Schob, ${ }^{1}$ and the baboons reported by Scherer, ${ }^{2}$ this animal suddenly became ill with paresis, ataxia, and intention-tremor.

Microscopic Examination. - The nervous system (cerebral hemispheres, cerebellum, pons, medulla oblongata, spinal cord, and optic tracts), partly fixed in alcohol and

* From the Deutsche Forschungsanstalt für Psychiatrie, Kaiser Wilhelm Institut, Munich, and the Neuropathological Laboratory, Montefiore Hospital, New York. 
partly in formalin, was studied with the Nissl, myelin sheath, Scharlach, Holzer, and Bielschowsky methods.

In myelin-sheath preparations (Spielmeyer's method) the white matter of the cerebral hemispheres contained small, irregular demyelinated plaques (fig. 1 a) scattered throughout, tending to group around the smaller vessels. Larger irregular plaques were also observed; these on closer examination were found to be the result of the fusion of several smaller plaques. In general, the $U$-fibres were spared, and no plaques involved the grey matter (fig. 1 a). Although the myelin sheaths within the

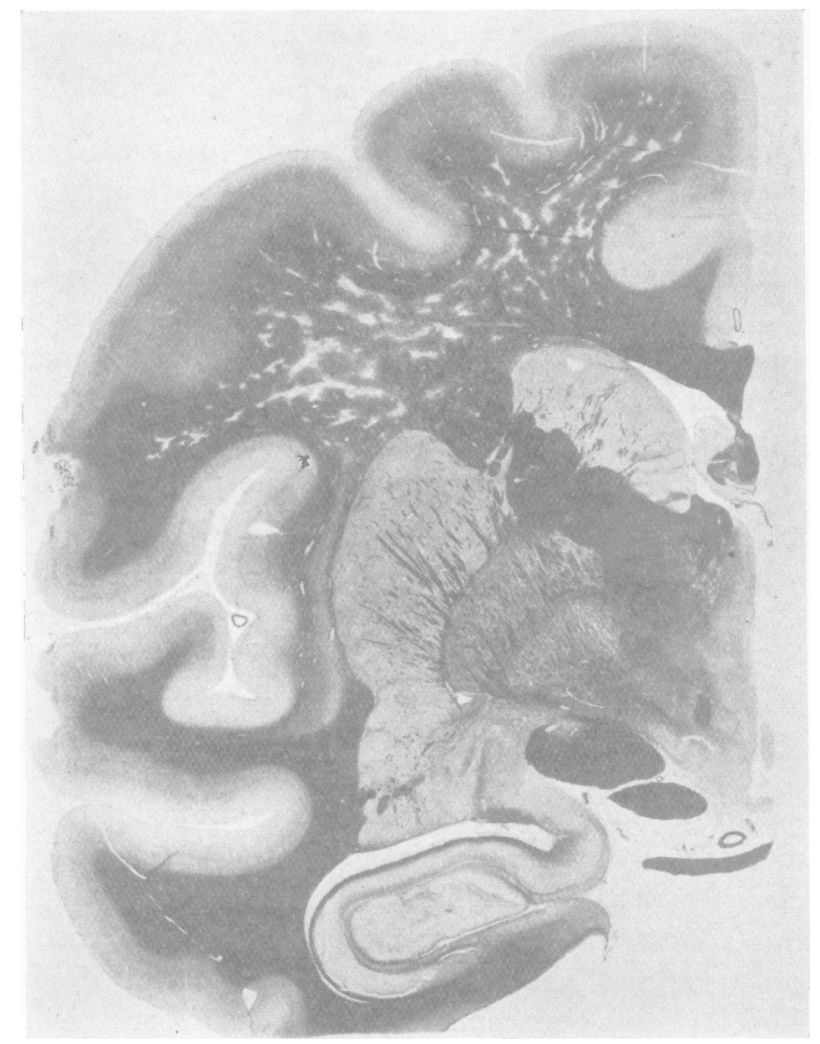

FIG. 1 (a).-Coronal section of the left hemisphere of the brain of a baboon (Papio cynocephalus) with demyelinated plaques in the white matter. Myelin-sheath stain (Spielmeyer).

plaques were destroyed, some axis-cylinders could still be identified. The demyelinated plaques were filled with cells which stained light brown.

In Nissl preparations the demyelinated areas of the white matter could be seen with the naked eye as specks which stained more deeply than the rest of the white substance (fig. $1 b$ ). The tendency of the smaller plaques to fuse was even more evident in these preparations than in the myelin-sheath sections. Larger plaques were also found. This was especially noticed in a coronal section through the central ganglia, where the superior surface of the white matter of the hemisphere appeared to be one confluent deeply stained mass (fig. 1 b). The plaques which were found in the 
white matter extending from the frontal to the occipital pole were most numerous in sections through the central sulcus (fig. $1 a$ ). The thalamic, hypothalamic and subthalamic nuclei, the internal capsule, the striatum, the central grey and the cortical grey matter were free from these collections. The cells in these areas consisted essentially of ' gemästete' glia-cells, most of which were grouped around small bloodvessels. Occasionally a ' gemästete' glia-cell was found in the region of the U-fibres, but never passing the arcuate fibres into the cortical grey matter. Compound granular corpuscles were also noted in the demyelinated zones. There was no evidence of

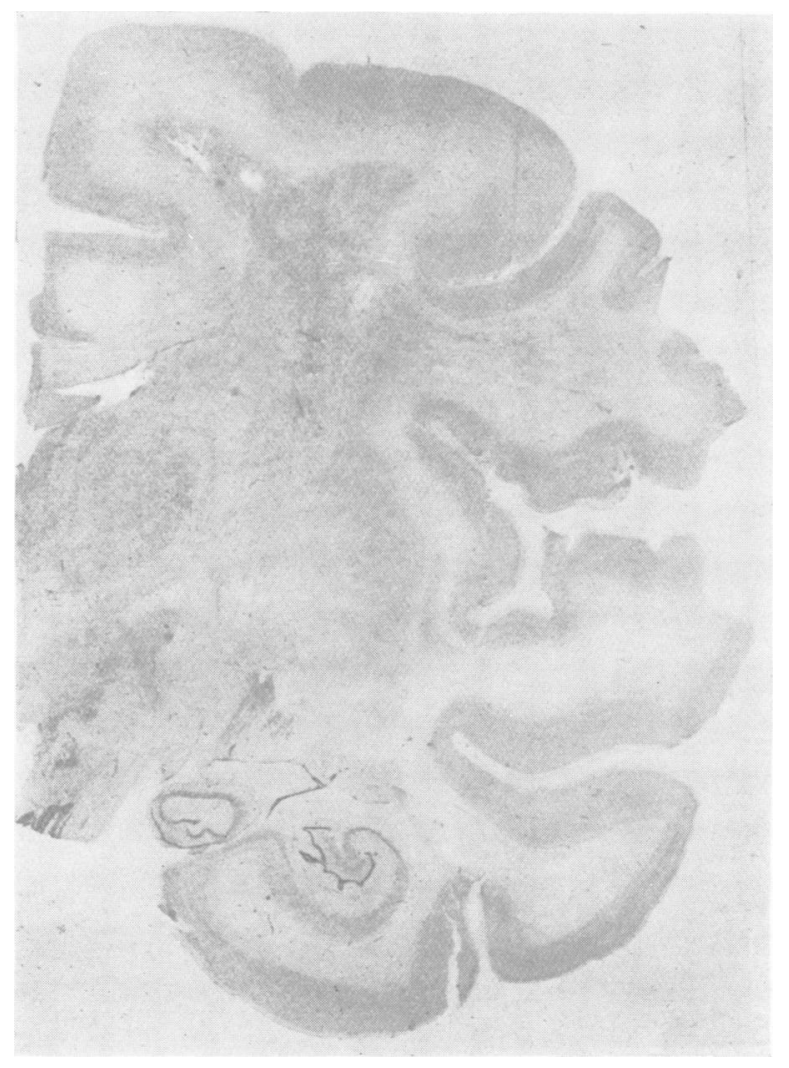

FIG. $1(b)$.--Right hemisphere showing the demyelinated plaques in the white matter consisting of deeply stained collections of cells. Nissl stain.

inflammatory cells. It should again be emphasized that the white and grey matter of the basal ganglia, pons, cerebellum and medulla oblongata was free from such collections of ' gemästete' glia-cells.

In Scharlach preparations the white matter of the cerebral hemisphere was filled with fatty products (fig. 2). Some of the plaques, which could easily be detected with this stain, contained less fat than other demyelinated areas. In places compound granular corpuscles (' gitter' cells) loaded with fat were observed. In the occipital regions the entire white matter of the cerebral hemisphere was filled with fatty products. The U-fibres were also infiltrated by these fatty deoosits. 
As in the Nissl preparations, the more deeply stained specks could be seen in the Holzer stain with the naked eye. These consisted of large irregular cells (' gemästete' glia-cells) containing a poorly stained cytoplasm and a more deeply stained nucleus which was generally located at the periphery (figs. $3 a$ and $b$ ). Some of the glia-cells also had short processes. As in previous sections the 'gemästete' glia-cells were perivascular in distribution (fig. $3 a$ ). Small glia-cells were also present. There was a slight perivascular gliosis (fig. $3 a$ ). In some areas the plaques had a honeycombed appearance.

Most of the axis-cylinders of the demyelinated plaques were destroyed; the few

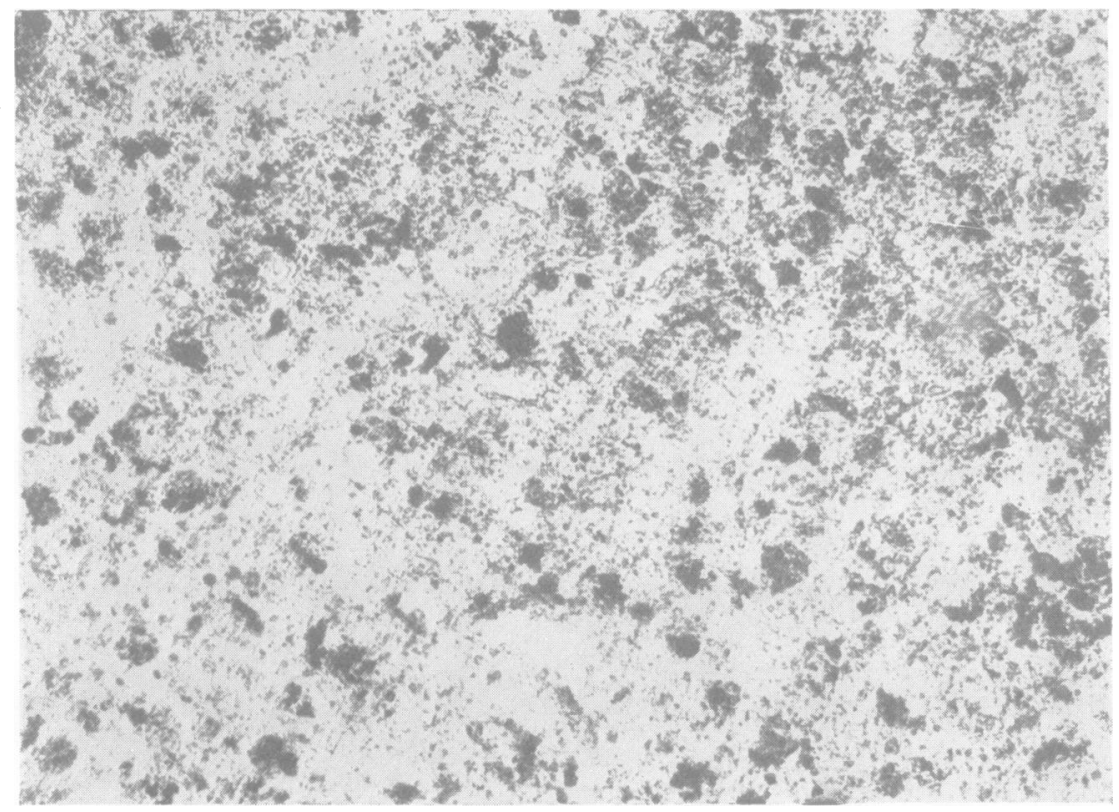

FIG. 2.-Fatty products fro:n the demyelinated areas. Scharlach stain.

axis-cylinders left were swollen and showed signs of disintegration (Bielschowsky method).

Optic Tracts and Chiasm. - Small demyelinated plaques were observed in myelinsheath and fat preparations. In contrast to the pathology of the white matter of the cerebral hemispheres the predominant cells in these structures were the compound granular corpuscles, 'gemästete' glia-cells being entirely absent. There was a generalized gliosis.

Spinal Cord.-Except for a secondary descending demyelinization of the pyramidal tracts, most marked in the thoracic and lumbar segments, the spinal cord showed nothing of note. The type of macroglia cells seen in the white matter of the cerebral hemisphere was totally absent in the cord.

\section{SUMMARY OF GASE}

A baboon (Papio eynocephalus) suddenly became ill with paresis of the extremities, ataxia, and intention-tremor. Histopathological studies revealed small demyelinated plaques scattered throughout the white matter of the 
cerebral hemispheres (figs. $1 \boldsymbol{a}$ and $\boldsymbol{b}$ ). The demyelinated areas consisted mostly of 'gemästete' glia-cells and a small number of compound granular corpuscles (figs. $3 a$ and $b$ ). The myelin-sheaths and axis-cylinders in these zones were partiy destroyed, but the $\mathbf{U}$-fibres were spared. The optic chiasm

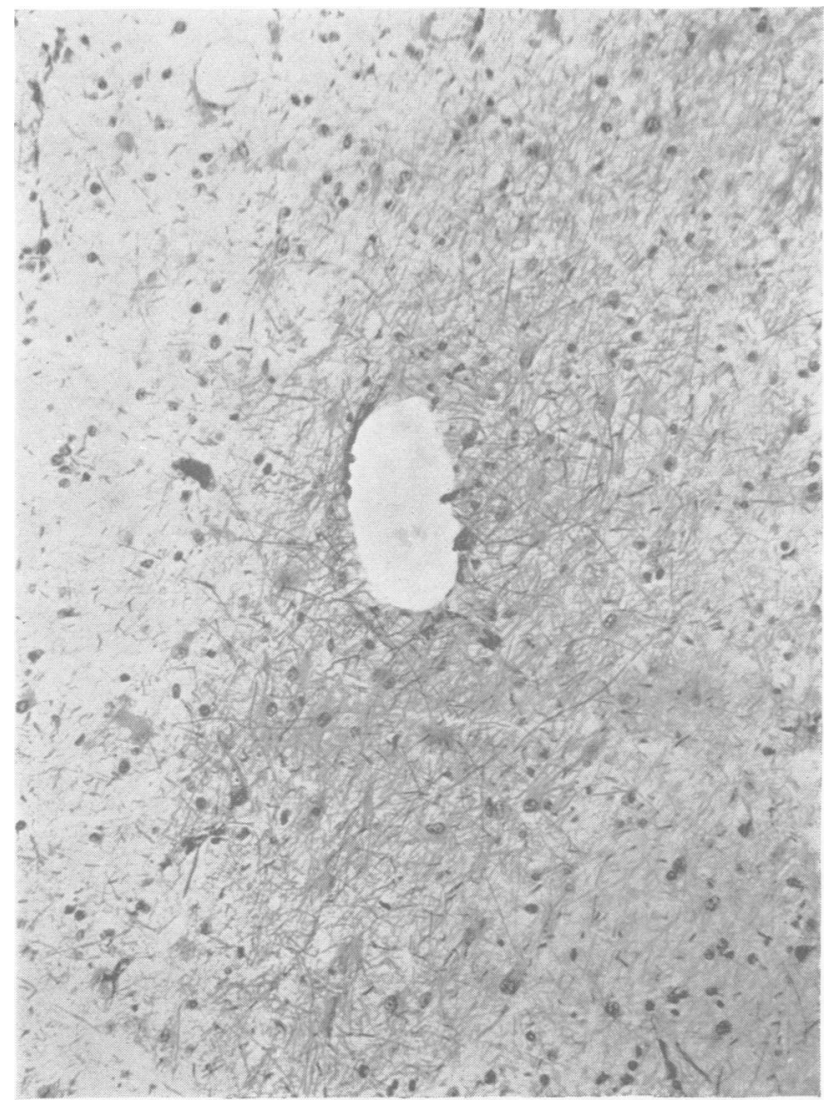

Fı̀. :3 (a).-Collection of ' gemästete' glia-cells and perivascular gliosis. Holzer stain.

and tract, except for the absence of ' gemästete ' glia-cells, were involved by a similar process. The spinal cord showed a secondary descending degeneration of the pyramidal tracts. The cortical grey matter and the grey and white matter of the basal ganglia, pons, cerebellum and medulla oblongata were free from this pathological process.

\section{DISGUSSION}

The histopathological findings in this animal and those described in the orang-outang by Schob $^{1}$ and in five other baboons by Scherer, ${ }^{2}$ as well as 
somewhat similar findings in apes by others (Schröder, ${ }^{3}$ Steiner, ${ }^{4}$ Rothmann, ${ }^{5}$ Levaditi, Lepine and Scoe, ${ }^{6}$ and Perdrau ${ }^{7}$ ) bring up the question of the relation of this disease to various neurological disorders such as tabes dorsalis, diffuse sclerosis, multiple sclerosis, funicular disease of the spinal cord (subacute combined degeneration) and xanthomatosis.

Rothmann and Schob considered the remote possibility of the relation-

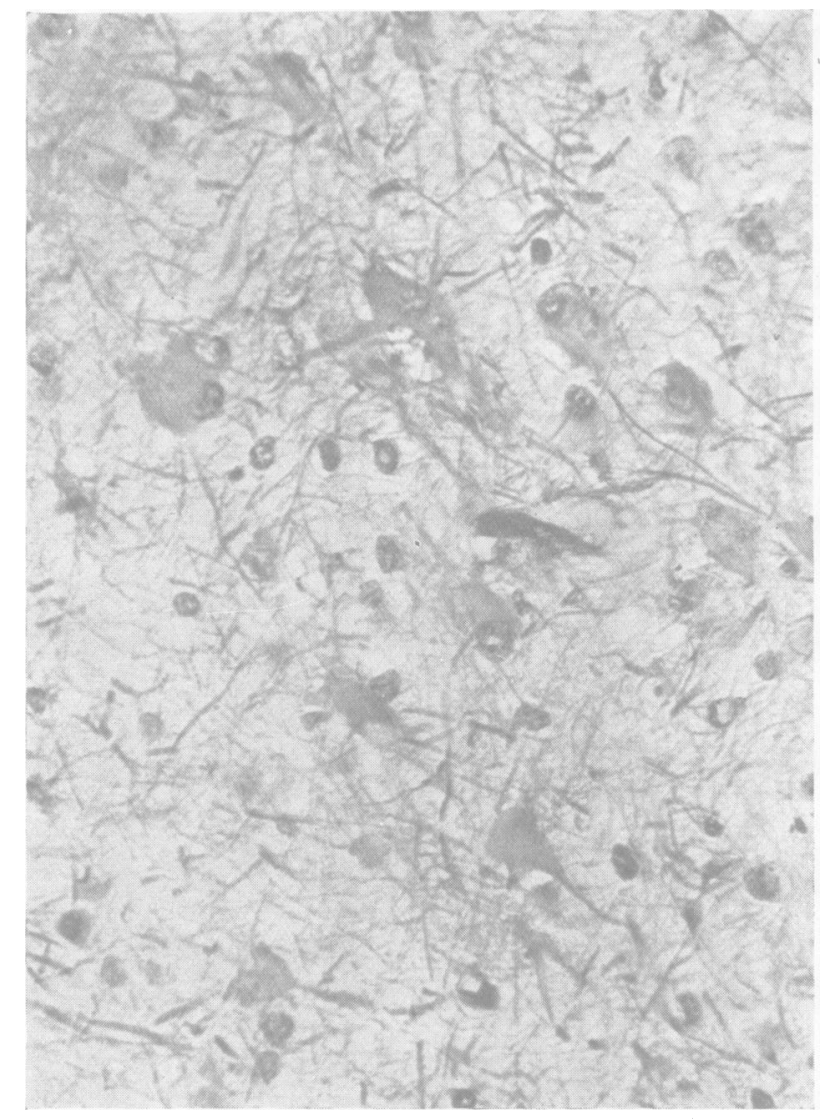

FI(x. $3(b) .-$ The same as fig. $3(a) . \times 400 . \quad$ Holzer stain.

ship of tabes dorsalis to the disseminated demyelinizations because of the lesions of the posterior columns and optic pathways in two animals. Rothmann's case, which presented a degeneration of the posterior columns, can be excluded from the diffuse demyelinating group, for the white matter of the cerebral heinisphere was completely free from demyelinated plaques. Rothmann was even sceptical about considering his case one of tabes, for in contrast to human tabes the main lesion was found in the thoracic region, 
while the lumbar cord was spared. Schob's first animal, in addition to multiple plaques of the white matter of the hemispheres and the optic pathways, also had a degeneration of all the posterior roots up to the dorsal region and an ascending degeneration of the posterior columns from the lumbar to the cervical region. A possible combination of such lesions in tabes dorsalis in the human subject is unknown. The lack of involvement of the grey matter in Schob's animal is sufficient reason to eliminate it from the taboparesis group.

Some of the observers (Levaditi, Lepine and Scoe, Perdrau) regarded the demyelinated plaques in the white matter of the hemispheres and the sparing of the U-fibres as suggestive of diffuse sclerosis. It should be emphasized that in diffuse sclerosis the process starts in the centre of the white matter and generally spreads to the periphery towards the $\mathbf{U}$-fibres, forming one or several large plaques. This was not observed in the baboon. Schob is inclined to think that the process in these monkeys is not the same as diffuse sclerosis in man because systemic disease of the posterior columns and optic nerves was so far not found in man. This may be true for the posterior columns. Optic nerve and tract changes, however, were recorded in the literature on diffuse sclerosis by Stewart, Greenfield and Blandy ${ }^{8}$ (Case II), Stauffenberg, ${ }^{9}$ Sheldon, Doyle and Kernohan, ${ }^{10}$ and Davison and Schick ${ }^{11}$. Although the histopathological findings described by Levaditi and Perdrau strongly suggest similarity to diffuse sclerosis, close observations of the demyelinated plaques demonstrate that the larger plaques are a fusion of the small demyelinated areas about the vessels, and not the end-result of continuous spreading of the plaque from one area generally situated near the ventricles.

Steiner at one time considered the findings in his ape analogous to those observed in multiple sclerosis. He has, however, since changed his opinion. The fairly uniform bilateral demyelinization of the white matter in both hemispheres, the absence of a well-defined border in the plaques, the presence of the status spongiosus and the sparing of the basal ganglia, pons and medulla oblongata (usual sites for multiple sclerotic plaques) speak against this diagnosis. It shouid be stressed that in multiple sclerosis the plaques are fairly well circumscribed, and that, although they involve the white matter essentially, they do nct necessarily spare the grey.

Schröder and, later, Scherer thought that they were confronted with a disease process somewhat similar to that found in toxic conditions-pernicious anæmia and cachexia. The demyelinization of the fibre tracts of the spinal cords in the first and second baboons and monkey Manga (Scherer) is suggestive of subacute combined degeneration (pernicious anæmia). Scherer calls the disease 'funicular spinal disease' and cautiously attempts to compare this process with that seen in pernicious anæmia. This he does on the basis of the pseudosystemic involvement of the posterolateral columns, the marked predilection of this process for the thoracic region of the spinal cord, the 
pronounced rapidity of destruction of tissue with the typical honeycombed appearance, and the absence of gliosis. Although the lesion of the spinal cord in pernicious anæmia may attack other pathways in man, it mainly involves the posterolateral columns. The almost equal distribution of the demyelinated areas in practically all the pathways of the spinal cord in the four monkeys of Scherer must be looked upon as a remarkable variation. $I^{12}$ have seen in four human beings a disease of the spinal cord where all fibre tracts were involved, the periphery more than the centre. Pernicious anæmia was definitely ruled out in these cases. Due to lack of knowledge of the retiological factors and a complete absence of inflammatory cells in the cord, these cases were labelled as 'toxic myelopathy.' The pathological process in the cord of these monkeys was somewhat similar to those I described in the myelopathies. Other points against the diagnosis of 'funicular spinal disease' in these monkeys were the constant changes in the white matter of the hemispheres. Cases of pernicious anæmia in man with destruction of the white matter of the cerebral hemispheres are well known (Weiman,13 Braun, ${ }^{14}$ Wohlwill, ${ }^{15}$ Bodechtel ${ }^{16}$ ), but these are rather unusual findings. In contrast they occurred commonly in Scherer's monkeys.

Other unusual findings, which rarely occur in pernicious anæmia, are the optic nerve and tract changes found in most of these monkeys. According to Scherer, the alterations in the opticus of monkey Manga were similar to those found by Bielschowsky ${ }^{17}$ in questionable cases (Cases III and IV) of subacute combined degeneration in man. Professor Spielmeyer, was kind enough to let me examine the optic nerves, tracts, chiasm and medulla oblongata from a patient diagnosed clinically as pernicious anæmia. Histopathologically, the lesions in these structures were suggestive of pernicious anæmia. The spinal cord, unfortunately, was not obtained at necropsy. The mere finding of optic nerve changes in only two or three questionable cases recorded in the literature is strongly suggestive of the rarity of such a process in pernicious anæmia. One can therefore state without hesitation that although some of the histopathological alterations in the cords in some of the animals are suggestive of subacute combined degeneration, the entire process is in all probability not the same as that occurring in pernicious anæmia. A point worth mentioning is that, so far, pernicious anæmia has not been transmitted to animals ; the horse is possibly the only animal which suffers from an anæmia approaching the pernicious type in man.

Further differentiation must also be made from postvaccinial and measles encephalitis. This is of importance in cases with small demyelinated plaques (Schröder, Steiner, Sch $n$ (Case Peter)), and in the present case. This differentiation is not diflic:ult when one recalls that in the postvaccinial and allied types of encephalitis the cortex and the other grey masses are not spared.

I 18 recently described a case of xanthomatosis (Schüller-Christian syndrome) with neurological symptoms. A complete necropsy, except for the 
spinal cord, was performed. The changes found in the nervous system were somewhat similar to the histopathological changes found in most of these animals.

In the case of xanthomatosis the white matter of the cerebral hemispheres, internal capsule, corpus callosum, thalamic nuclei, corpus striatum, tuber cinereum, pons and medulla oblongata showed scattered plaques of demyelinization (figs, $4 a$ and $b$ ). The myelin in these plaques was destroyed,

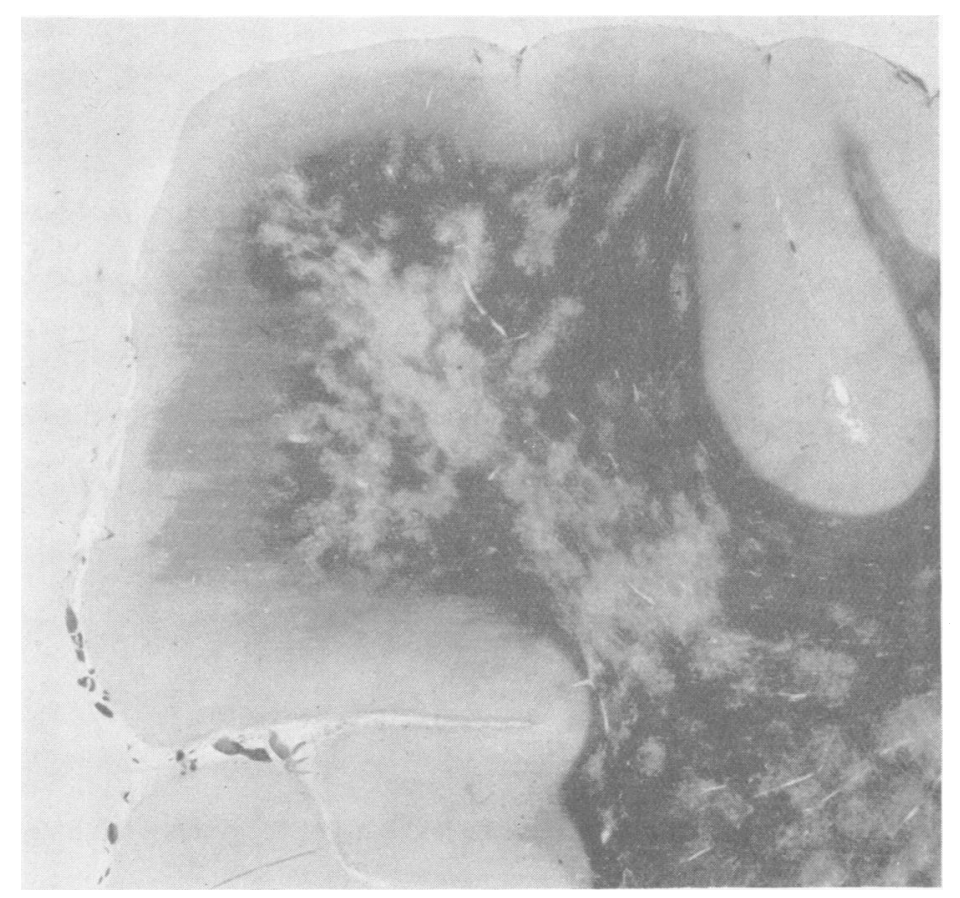

FIc: $+(a)$.-Demyelinated plaques in the white matter. Myelin-sheath stain.

and replaced by ' gemästete' glia-cells. The U-fibres were more or less spared. The larger plaques were definitely the end-result of fusion of the smaller plaques. The cells forming these plaques (fig. 5) were best observed in cresyl-violet preparations. With the Fett-Ponceau and Sudan IV stains many of the 'gemästete' glia-cells were seen to be loaded with fat. Disintegration products were also noticed. Some of the substances stained for fat were doubly refractile. The axis-cylinders in these areas were also partially destroyed, but suffered less than the myelin-sheaths. The destroyed areas were replaced by glia-cells and -fibres. The optic nerves and tracts also showed demyelinated zones filled with ' gemästete' glia-cells. 
When the case was studied the following question presented itself : Did the 'gemästete' glia-cells play the same rôle in the central nervous system as the 'foam-cells' in the other organs? As is well known, xanthomatosis is considered by many observers a disease of lipoid metabolism, like Gaucher's, Nieman-Pick's, and possibly amaurotic family idiocy. If the demyelinated plaques in the baboon are accepted as being analogous to those in the xanthomatosis case, then a disturbance in lipoid metabolism might be

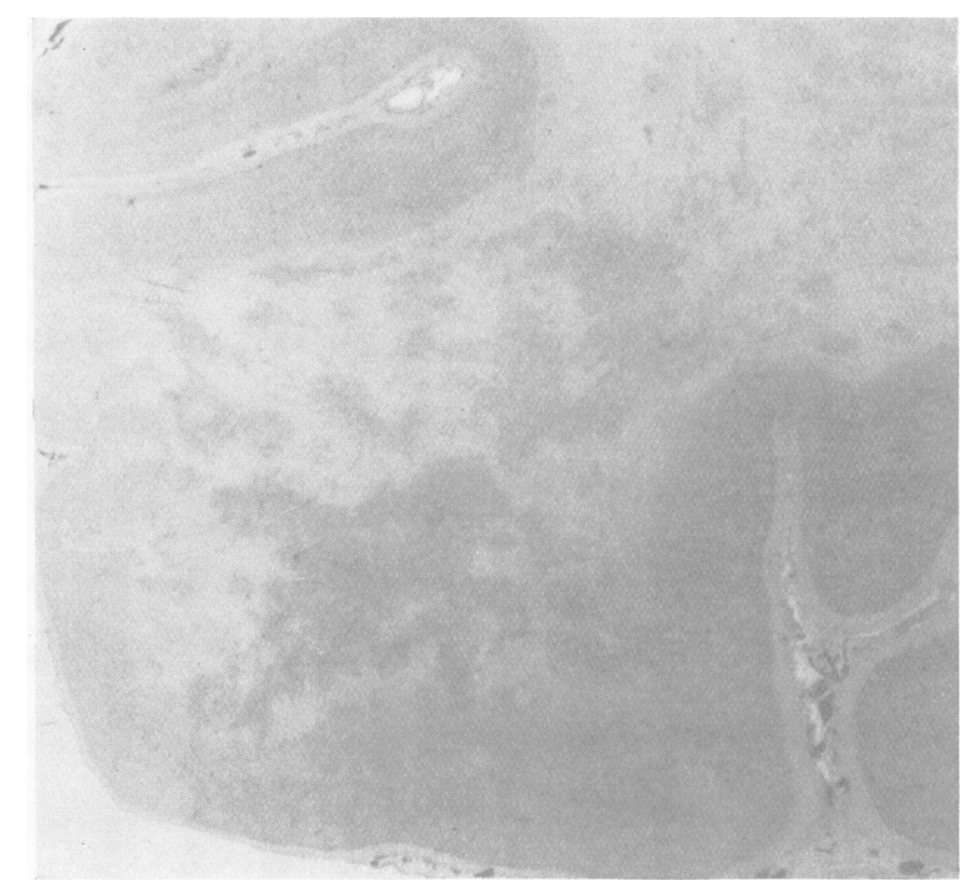

FI(i. $+(b)$. - The same as fig. $4(a)$. The demyelinated plaques are seen as deeply stained collections of cells in the white matter. Cresyl-violet stain.

considered a possibility. As we know little of the rtiology of diffuse sclerosis, pernicious anæmia, xanthomatosis and the process in these monkeys, I am offering this speculation with hesitation. Further careful studies in metabolism might give us a clue to the cause of this process.

It must be emphasized that a reconstruction of a disease-process from the pathological picture alcne is dangerous. The exact clinical data and xtiological factors must be ascertained. We know that the same type of cell changes may occur in different diseases, due to different actiological factors. For this reason we should hesitate to state that we are dealing in these monkeys with diffuse sclerosis, multiple sclerosis, subacute combined degeneration or xanthomatosis just because there was a suggestive similarity in the 
pathological picture. In the absence of any xtiological evidence, we are justified in considering such a possibility, but these cases should be further investigated along bacteriological and biochemical lines. Until then we are forced to resort to the scanty clinical facts and comparative pathology:

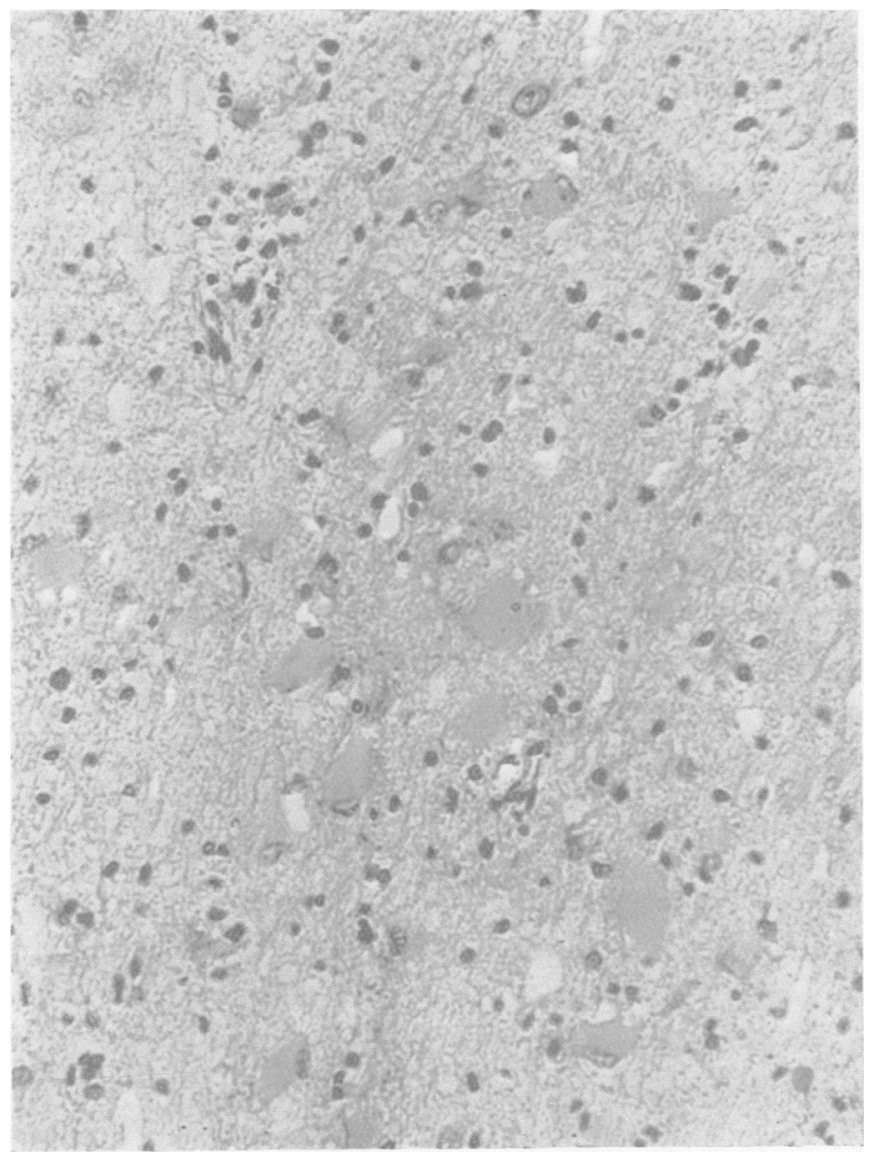

Fig. 5.- 'Gemästete' glia-cells from the demyelinated plaques. Cresyl-violet stain.

\section{GONGLUSIONS}

Numerous small demyelinated plaques were found scattered throughout the white matter of the cerebral hemispheres and optic tracts of a baboon which suddenly became ill with paresis, ataxia and intention-tremor. The demyelinated plaques consisted essentially of 'gemästete' glia-cells. These pathological findings are compared with those in multiple sclerosis, diffuse sclerosis, subacute combined degeneration and xanthomatosis. 


\section{REFERENGES}

1 Sснов, 'Disseminirte, konfiuirende Sklerose des Hemisphärenmarklagers des Affen kombiniert mit systematischer Erkrankung des Sehnerven sowie der Hinterwurzeln und Hinterstränge,' Zeits.f. d. g. Neurol. u. Psychiat., 1931, 135, 95.

2 Scherer, 'Funikuläre Spinalerkrankungen mit schwerer Beteiligung des Grosshirnmarkes und Opticusveränderungen bei fünf Pavianen,' Zeits.f. d. g. Neurol. u. Psychiat., 1932, 141, 212.

${ }^{3}$ Schroder, 'Über eine Hinterstrang- und Sehnerverkrankung beim Affen,' Arch. $f$. Psychiat., 1908, 44, 193.

4 Steiner, 'Multiple und diffuse Sklerose,' Bumke's Handb. der Geisteskrankheiten, Bd. 11, 1930.

5 Rothmann, ' Uber ein tabesartige Erkrankung beim Affen,' Monats. f. Psychiat. $u$. Neurol., 1906, 20, 204.

' Levaditi, Lepine and Scoe, 'Maladie de Schilder-Foix spontanée chez le singe,' Société de biologie, Paris, 1930.

7 Perdrau, 'Schilder's encephalitis periaxialis diffusa in a rhesus monkey,' Jour. of Pathol., 1930, 33, 991.

${ }^{8}$ Stewart, Greenfield and Blandy, 'Encephalitis periaxialis diffusa,' Brain, $1927,50,1$.

${ }^{9}$ Stauffenberg, ' Ein Fall von Encephalitis periaxialis diffusa,' Zeits. f. d. g. Neurol. u. Psychiat., 1913, 39, 56.

10 Sheldon, Doyle and Kernohan, 'Encephalitis periaxialis diffusa,' Arch. Neurol. and Psychiat., 1929, 21, 1270.

11 Davison, C., and Schick, W., 'Encephalopathia periaxialis diffusa (Schilder's disease),' Arch. Neurol. and Psychiat., 1931, 25, 1063.

12 Davison, C., and Keschner, M., 'Myelitic and myelopathic lesions : II. Toxic myelopathy,' Arch. Neurol. and Psychiat., 1933, 29, 600.

13 Weimann, ' Grosshirnveränderungen bei Anæmie,' Zeits.f. d.g. Neurol. u. Psychiat., $1924,92,433$.

14 Braun, ' Úber Hirnveränderungen bei funikulären Erkrankung des Rückenmarkes,' Arch. f. Psychiat., 1924, '70, 133.

15 Wohlwill, 'Funikuläre Myelose und Myelitis,' Deut. Zeits. f. Nervenheilk., 1931, 117-119, 776.

16 Bodechtel, 'Zur Histopathologie der funikulären Spinalerkrankung,' Zeits. f. $d$. g. Neurol. u. Psychiat., 1931, 13\%, 104.

17 Bielschowsky, Myelitis und Sehnervenentzündung, Berlin, 1901.

18 Davison, C., 'Xanthomatosis (Schüller-Christian syndrome) and the central nervous system,' Arch. Neurol. and Psychiat., 1933, 30, 75. 